\title{
GOOD FAITH IN TRIPS COMPULSORY LICENSING OF PHARMACEUTICAL PATENTS: LESSONS FROM PREVIOUS PANDEMIC CASES
}

\author{
Muhammad Ardiansyah Arifin \\ Faculty of Law, Universitas Gadjah Mada, Indonesia, \\ E-mail: muhammadardiansyah00@ mail.ugm.ac.id
}

Submitted: June 25, 2021; Reviewed: July 28, 2021; Accepted: August 8, 2021

\begin{tabular}{|c|c|}
\hline Article Info & Abstract \\
\hline $\begin{array}{l}\text { Keywords: } \\
\text { Compulsory Licensing, COVID-19, } \\
\text { International, TRIPS Agreement. }\end{array}$ & $\begin{array}{l}\text { The COVID-19 pandemic impacts the world of patents as } \\
\text { countries prepare their legal framework to ease the } \\
\text { process of compulsory licensing. Some like India and } \\
\text { South Africa even went further by proposing a suspension }\end{array}$ \\
\hline $\begin{array}{l}\text { DOI: } \\
\text { 10.25041/lajil.v3i2.2349 }\end{array}$ & $\begin{array}{l}\text { for patents needed to combat COVID-19 which is still } \\
\text { under discussion. It is a real possibility that a patented } \\
\text { drug that is effective against COVID-19 would potentially } \\
\text { see compulsory licensing in many countries its patent } \\
\text { holder is doing business. This article discusses why } \\
\text { compulsory licensing is an essential issue by examining } \\
\text { its legitimacy, previous cases of compulsory licensing, } \\
\text { and the conduct of states in cases of compulsory licensing } \\
\text { issuance, particularly in examples of Thailand, Brazil, } \\
\text { and India. The article will examine ways of remedy } \\
\text { against compulsory licensing, including a theoretical } \\
\text { possibility for constitutional review of treaties. The } \\
\text { remedies discussed shall include international and } \\
\text { domestic remedies, both litigation and alternative } \\
\text { measures. The research shall use qualitative research } \\
\text { methods with the use of primary and secondary legal } \\
\text { sources. The result of this article found that a } \\
\text { combination of soft law power of the Doha Declaration } \\
\text { and the invocation of subsequent compulsory licensing } \\
\text { cases be the support pillars of compulsory licensing } \\
\text { practice. However, the practice of compulsory licensing } \\
\text { both by the patent holder and the state actors is still not } \\
\text { performed entirely in good faith according to the Vienna } \\
\text { Convention of the Law of Treaties (VCLT) 1969 and the } \\
\text { TRIPS Agreement. Hence, such patent holders need to be } \\
\text { familiar with both international and domestic remedies, } \\
\text { especially the possibility for constitutional review of } \\
\text { treaties remedies. }\end{array}$ \\
\hline
\end{tabular}




\section{A. Introduction}

The need for greater access towards COVID-19 medicines has propelled risks that countries adopt measures ranging from waiver of intellectual property enforcement as a measure to deal with COVID-19 back in 15-16 October $2020,{ }^{1}$ overriding the protection of intellectual property under Article 73 of TRIPS as part of security exception, ${ }^{2}$ revocation, and forfeiture under Article 32 of TRIPS, ${ }^{3}$ and finally-perhaps the most moderate approach aside from voluntary licensing-the Compulsory licensing measures under Article 31 jo Article 31 bis of TRIPS. All actions above are part of the flexibilities under the TRIPS Agreement and potentially used by state parties to aid their effort in combating the spread of COVID-19. ${ }^{4}$

For example, the Saudi Arabia-IPR Panel and the Russia-Transit Panel recognized that security exceptions of Article 73 of the TRIPS Agreement could be made without analyzing fewer trade-restrictive measures or alternatives. The actions need to be plausibly related to its objectives. However, the implementation of Article 73 would potentially trigger other obligation issues in the form of domestic laws and Investment Agreements (IAs), which a country could possess. ${ }^{5}$ The trigger of other obligation issues might be why there is no use of Article 73 yet in appropriating covid-19 medical materials. ${ }^{6}$

The revocation and forfeiture of COVID-19 medicines under Article 32 of the TRIPS Agreement is laxer by itself. ${ }^{7}$ It only requires that there needs to be a judicial review process mechanism before state parties conduct forfeiture or revocation. However, the lax requirement is balanced with the compulsory obligation to comply with The Paris Convention for the Protection of Industrial Property (Paris Convention 1979) of Article 1 to Article 12 and 19. This is different from compulsory licensing for pharmaceutical products under Article 31 jo Article 31 bis of TRIPS.

Compulsory licensing is a license issued by a country's government to a third party to produce a patented product without its owner's permission. ${ }^{8}$ The general requirements are to conduct compulsory licensing include the supply of the domestic market. Unless the country does not have sufficient manufacturing capabilities in the pharmaceutical sector, the use shall be for public and non-commercial purposes. The right holder must be informed promptly. ${ }^{9}$ Compulsory licensing is often the preferred method by state parties in acquiring medical supplies.

\footnotetext{
${ }^{1}$ Hans Morten Haugen, "Does TRIPS (Agreement on Trade-related Aspects of Intellectual Property Rights) Prevent COVID-19 Vaccines as a Global Public Good?," The Journal of World Intellectual Property 24, no. 3-4 (2021): 1-26, https://doi.org/10.1111/jwip.12187.

${ }^{2}$ Frederick M. Abbott, "The TRIPS Agreement Article 73 Security Exceptions and the COVID-19 Pandemic," SSRN Electronic Journal, no. 116 (2020): 1-22, https://doi.org/10.2139/ssrn.3682260.

${ }^{3}$ Carlos M. Correa, "Special Section 301: US Interference with the Design and Implementation of National Patent Laws," Research Paper (Geneva, 2020).

${ }^{4}$ Haugen, "Does TRIPS (Agreement on Trade-related Aspects of Intellectual Property Rights) Prevent COVID19 Vaccines as a Global Public Good?"; Abbott, "The TRIPS Agreement Article 73 Security Exceptions and the COVID-19 Pandemic."

${ }^{5}$ Abbott, "The TRIPS Agreement Article 73 Security Exceptions and the COVID-19 Pandemic."

${ }^{6}$ Katrina Perehudoff, Ellen Thoen, and Pascale Boulet, "Overriding Drug and Medical Technology Patents for Pandemic Recovery: A Legitimate Move for High-Income Countries, Too," BMJ Global Health 6, no. 4 (2021): 1-4, https://doi.org/10.1136/bmjgh-2021-005518.

${ }^{7}$ Haugen, "Does TRIPS (Agreement on Trade-related Aspects of Intellectual Property Rights) Prevent COVID19 Vaccines as a Global Public Good?"

${ }^{8}$ Eduardo Urias and Shyama V. Ramani, "Access to Medicines after TRIPS: Is Compulsory Licensing an Effective Mechanism to Lower Drug Prices? A Review of the Existing Evidence," Journal of International Business Policy 3, no. 4 (2020): 367-84, https://doi.org/10.1057/s42214-020-00068-4.

${ }^{9}$ Haugen, "Does TRIPS (Agreement on Trade-related Aspects of Intellectual Property Rights) Prevent COVID19 Vaccines as a Global Public Good?"; Dawn Dziuba, "Trips Article 31bis and H1N1 Swine Flu: Any Emergency or Urgency Exception to Patent Protection?," Indiana International \& Comparative Law Review 20, no. 2 (January 2010): 195-212, https://doi.org/10.18060/17626.
} 
This is proven by previous cases before COVID-19 when countries implemented compulsory licensing in coping with previous pandemics. For example, in the HIV/AIDS pandemic, countries such as Kenya, Zimbabwe, Benin, Congo, Ivory Coast, Mozambique, Togo, Zambia, Central African Republic, Chad, Gambia, Guinea, Lesotho, Malawi, Niger, Rwanda, and Sierra Leone all have invoked compulsory licensing. ${ }^{10}$ Furthermore, compulsory licensing does not always happen in a pandemic. An example is when the United States of America (USA) issued a compulsory license for sofosbuvir to increase access for the treatment of Hepatitis. Moreover, the British government has compulsory licenses towards lumacaftor/ivacaftor to increase access to cystic fibrosis treatment. ${ }^{11}$

For COVID-19 related medicines, there are currently two confirmed executed compulsory licensing. Russia has issued a compulsory license towards Gilead, allowing local Russian company Pharmsynthez to produce COVID-19 emergency drug remdesivir. Israel also has issued a compulsory license for an experimental COVID-19 drug called lopinavir/ritonavir (LPV/r). ${ }^{12}$ The lack of effective medicines caused the current low number of compulsory licensing because it is still developing. Existing drugs are in the experimental stage or do not have a significant clinical outcome towards COVID-19, making countries hesitant. ${ }^{13}$

It is a real possibility that when an effective drug against COVID-19 exists, countries worldwide will use voluntary or compulsory licensing to get such medicines. For example, countries such as Ecuador have approved a resolution calling for its health minister to issue a private license for all patents related to COVID-19. In contrast, countries like Brazil, Canada, Chile, and Germany have amended their patent laws allowing for faster granting of compulsory licenses or laying the groundwork for easing COVID-19 related licensing issuances. ${ }^{14}$

This trend is further exacerbated with a proposal from India and South Africa, which calls for suspension of COVID-19 related intellectual property protection to widen the access of COVID-19 related materials for developing and least developing countries. Currently, this proposal is still in discussion. ${ }^{15}$ Therefore, all relevant parties need to learn about previous cases of compulsory licensing invocation and available remedies against compulsory licensing to avoid past mistakes and ensure fairness in its implementation.

Previous articles such as what has been discussed by Tariq Kameel, Ramzi Madi, and Kawthar Kayed only discuss legal approaches in Arabian countries to identify when compulsory license could be issued and the right of a patent owner to fair compensation. ${ }^{16}$ Hilary Wong did discuss past experiences in the issuance of compulsory licensing of previous

\footnotetext{
${ }^{10}$ Marion Motari et al., "The Role of Intellectual Property Rights on Access to Medicines in the WHO African Region: 25 Years after the TRIPS Agreement," BMC Public Health 21, no. 1 (2021): 1-19, https://doi.org/10.1186/s12889-021-10374-y.

${ }^{11}$ Perehudoff, Thoen, and Boulet, "Overriding Drug and Medical Technology Patents for Pandemic Recovery: A Legitimate Move for High-Income Countries, Too."

12 Perehudoff, Thoen, and Boulet.

${ }^{13}$ Hilary Wong, "The Case for Compulsory Licensing during COVID-19," Journal of Global Health 10, no. 1 (June 2020): 1-5, https://doi.org/10.7189/jogh.10.010358.

${ }^{14}$ Nataliia Serohina et al., "Application of Compulsory Licensing in the Context of the Covid-19 Coronavirus Pandemic," Systematic Reviews in Pharmacy 12, no. 1 (2021): 334-42, https://doi.org/10.31838/srp.2021.1.53; Sakinah Mohd Shukri, Johar MGM, and Jacquline Tham, "How E-Business Platform Channels Influence Chinese Auto-Parts Wholesale Market?," Systematic Reviews in Pharmacy 11, no. 1 (2020): 718-24, https://www.sysrevpharm.org/articles/role-of-ebusiness-in-the-wholesale-market-of-china.pdf; Wong, "The Case for Compulsory Licensing during COVID-19."

15 Ann Danaiya Usher, "South Africa and India Push for COVID-19 Patents Ban," The Lancet 396, no. 10265 (December 2020): 1790-91, https://doi.org/10.1016/S0140-6736(20)32581-2; Vijay Kumar Chattu, Shalini Pooransingh, and Hamid Allahverdipour, "Global Health Diplomacy at the Intersection of Trade and Health in the COVID-19 Era.," Health Promotion Perspectives 11, no. 1 (2021): 1-4, https://doi.org/10.34172/hpp.2021.01.

16 Tariq Kameel, Ramzi Madi, and Kawthar Kayed, "The Compulsory Licensing for Exploiting Patented COVID19 Pharmaceutical Treatment: Legal Approaches of Some Arab Countries," Biotechnology Law Report 40, no. 2 (2021): 104-16, https://doi.org/10.1089/blr.2021.29225.ka.
} 
pandemics. Still, it did not discuss legal avenues that countries or patent owners could take in the case of being served with compulsory licensing. ${ }^{17}$ Another article by Hans Morten Haugen discussed how and when licensing could be legally invoked. It again did not discuss remedies that could be taken by patent owners facing compulsory licensing, and its main focus is the embedded progress of human rights in the intellectual property regime for the last twenty years. ${ }^{18}$ The closest example to this article is a work by Alison Slade where it discusses the good faith principle under TRIPS Agreement. Still, it does not touch the matter of compulsory licensing. ${ }^{19}$

This research paper aims to discuss the urgency of the compulsory licensing issue and the remedies that concerned parties could pursue should they find themselves served with compulsory licensing. Since there is a scholarly vacuum on how good faith operates in compulsory licensing and varying legal remedies that could be taken in the case of compulsory licensing? To answer such questions, this paper will elaborate on the development history of compulsory licensing under the TRIPS Agreement to find out its benefits and issues to discuss ways in which concerned parties could seek remedies both domestic and abroad against compulsory licensing.

The method used to research this Article shall be a normative qualitative research method using secondary sources obtained by literature research containing secondary sources, mainly primary legal sources and secondary legal sources. First, this article will discuss the required licensing method of the TRIPS Agreement. Second, this article will discuss previous cases of compulsory licensing by citing examples of Thailand, Brazil, and India with the United States as the patent flag state. Thailand, Brazil, and India were chosen for this article because the three countries represent case examples of compulsory licensing, which the TRIPS Agreement served as a legal source. Moreover, many materials about the three countries show the interplay between patent holder state and compulsory licensing state. The three countries also face problems from one patent holder state: The United States. Because of its aggressive role in defending patents, the United States was chosen as a patent holder state example in this article. It is hoped that this research will bring further attention to compulsory licensing issues and their available legal remedies. Hence, both the rights of people and the pharmaceutical actors are better protected.

\section{B. Discussion}

\section{Compulsory Licensing Method in TRIPS Agreement}

Although having existed since 1623 from United Kingdom (UK) practice, ${ }^{20}$ the compulsory licensing method first gains prominence as a punitive measure under the Trading with the Enemy Act 1917. The United States government confiscated all German inventors and German-owned patents in the United States, where 4706 patents were made for compulsory licensing. ${ }^{21}$ Nowadays, compulsory licensing is used to weaken the monopoly power of patents.

\footnotetext{
${ }^{17}$ Wong, "The Case for Compulsory Licensing during COVID-19."

${ }^{18}$ Haugen, "Does TRIPS (Agreement on Trade-related Aspects of Intellectual Property Rights) Prevent COVID19 Vaccines as a Global Public Good?"

${ }^{19}$ Alison Slade, "Good Faith and the TRIPS Agreement: Putting Flesh on the Bones of the TRIPS 'Objectives,", International and Comparative Law Quarterly 63, no. 2 (April 2014): 353-83, https://doi.org/10.1017/S0020589314000098.

${ }^{20}$ Ebenezer Durojaye, "Compulsory Licensing and Access to Medicines in Post Doha Era: What Hope for Africa?," Netherlands International Law Review 55, no. 1 (May 2008): 33-71, https://doi.org/10.1017/S0165070X08000338.

${ }^{21}$ Joerg Baten, Nicola Bianchi, and Petra Moser, "Compulsory Licensing and Innovation - Historical Evidence from German Patents after WWI," Journal of Development Economics 126 (2017): 231-42, https://doi.org/10.1016/j.jdeveco.2017.01.002.
} 
The ratio for today's role of compulsory licensing is to weaken patents' monopoly power by increasing access to medicines and essential innovations as compulsory licensing results in sharp price reduction of the licensed goods. ${ }^{22}$

Compulsory licensing was included in Article 5 of the Paris Convention $1979,{ }^{23}$ before later complemented with Article 31 of the TRIPS Agreement 1994, foreign patents could be issued with compulsory licenses in case of national emergencies. ${ }^{24}$ The Doha Declaration further eases the compulsory licensing requirements by giving countries freedom to determine the grounds on which compulsory licenses are granted which clarifies the objectives and principles in interpreting the TRIPS Agreement. ${ }^{25}$ The objectives and principles of the TRIPS Agreement are enshrined in Article 7 and Article 8. Among the objectives enshrined in Article 7 is the promotion of social and economic welfare. This means the enforcement of intellectual property rights is a reward for its holder and creators that contributes to society in socioeconomic welfare. ${ }^{26}$

Before the Doha Declaration, there were two perspectives in interpreting the TRIPS Agreement objectives and purposes between South Africa, which favors the developing country approach, and the United States, which favors the developed countries' approach. This difference was originated from South African legislation, which allows compulsory licensing for pharmaceutical products, much to the United States' disagreement. ${ }^{27}$

South Africa argued that issuing compulsory licenses will cause prices to drop, increasing access to licensed medicines needed to handle the AIDS crisis back in $1997 .{ }^{28}$ While the United States argued that what is needed is a robust patent regime with a combination of social, economic, and health policies instead of compulsory licenses because such policies will encourage innovation and development of drugs. ${ }^{29}$ Regardless, the United States and the developed countries have moved away from their previous position. This mainly started from a turning point in the negotiation process when it is known that the United States threatened Bayer AG Corporation during the Anthrax ${ }^{30}$ scare to issue a compulsory license unless the corporation sold its ciprofloxacin license for a lower price. ${ }^{31}$

\footnotetext{
22 Petra Moser, "Patents and Innovation: Evidence from Economic History," Journal of Economic Perspectives 27, no. 1 (February 2013): 23-44, https://doi.org/10.1257/jep.27.1.23; Sara M Ford, "Compulsory Licensing Provisions Under the TRIPs Agreement: Balancing Pills and Patents," American University Journal of International Law \& Policy $15, \quad$ no. $4 \quad 4 \quad$ (2000): https://digitalcommons.wcl.american.edu/auilr/vol15/iss4/5/.

${ }^{23}$ Margaret Dowie-Whybrow, "Paris Convention for the Protection of Industrial Property," in Core Statutes on Intellectual Property (London: Macmillan Education UK, 2013), 516-43, https://doi.org/10.1007/978-1-13735471-6_5.

24 Antony Taubman, Hannu Wager, and Jayashree Watal, eds., “Agreement on Trade-Related Aspects of Intellectual Property Rights (TRIPS Agreement) (as Amended on 23 January 2017)," in A Handbook on the WTO TRIPS Agreement (Cambridge University Press, 2020), 295-337, https://doi.org/10.1017/9781108883511.015.

25 James Thuo Gathi, "The Legal Status of the Doha Declaration on TRIPS and Public Health Under the Vienna Convention of the Law of Treaties," Harvard Journal of Law \& Technology 15, no. 2 (2002): 292-317, https://lawecommons.luc.edu/cgi/viewcontent.cgi?article=1419\&context=facpubs; Moser, "Patents and Innovation: Evidence from Economic History."

${ }^{26}$ Thamara Romero, "Articles 7 and 8 as the Basis for Interpretation of the TRIPS Agreement" (Geneva, 2020).

${ }^{27}$ Ford, "Compulsory Licensing Provisions Under the TRIPs Agreement: Balancing Pills and Patents."

${ }^{28}$ Ford.

${ }^{29}$ Gathi, "The Legal Status of the Doha Declaration on TRIPS and Public Health Under the Vienna Convention of the Law of Treaties."

${ }^{30}$ Anthrax is caused by a spore-forming bacterium. It mainly affects animals.

31 Divya Murthy, "The Future of Compulsory Licensing: Deciphering the Doha Declaration on the TRIPs Agreement and Public Health," American University International Law Review 17, no. 6 (2002): 1299-1346, https://digitalcommons.wcl.american.edu/auilr/vol17/iss6/4/.
} 
Despite the consensus reached in the Doha Declaration, its legal status remains ambiguous; ${ }^{32}$ this is not categorized as a proper and official interpretation tool under Article IX.2 of the Marrakesh Agreement Establishing the WTO. ${ }^{33}$ There are three possibilities regarding the legal status of the Doha Declaration: As a subsequent agreement under Article 31.3 (a) of the Vienna Convention on Law of Treaties (VCLT) 1969, as evidence of subsequent practice under the TRIPS Agreement, or as a legally non-binding statement of intent and commitment. ${ }^{34}$

However, recent publications agree that the Doha Declaration is a legally non-binding statement of intent or "soft law" based on its text and negotiating history. ${ }^{35}$ There are differences of opinion among scholars about the role of soft law, mainly centered on whether it could be classified as a law in the first place. ${ }^{36}$ Positivist scholars such as Jan Klabbers strictly adhered to a view that "soft law" is not a law because the binding power of law cannot be uncertain, ${ }^{37}$ and Malcolm N. Shaw and Dinah Shelton further explain that instruments of "soft law" that have become legally binding are not soft law but rather international conventions or international customary law adopted from soft law. ${ }^{38}$

Some scholars take an interactionist approach towards soft law. These scholars do not expressly state whether "soft law" could be classified as law or not. Peter Malanczuk claims that soft law is a crossroad between law and politics; a soft law with high legitimacy could structure international conduct even though the soft law was intended to be non-legally binding. ${ }^{39}$ This shows a mutual reinforcing and supplementing approach towards hard and soft law relations, which Fuller supports. ${ }^{40}$

Aside from the positivist and interactionist approach, recent reviews by constructivists tried to argue the status of soft law as law. The constructivist approach claims that earlier scholars are biased because of positivist domination in the legal school of thought and ignore formal and informal law. For the constructivist, the law is not a closed system, and therefore the quality of legal argument determines the truth of the legal proposition instead of the other way around. ${ }^{41}$

\footnotetext{
32 Steve Charnovitz, "The Legal Status of the Doha Declarations," Journal of International Economic Law 5, no. 1 (March 2002): 207-11, https://doi.org/10.1093/jiel/5.1.207.

${ }^{33}$ Putu Ayu and Sriasih Wesna, "Doha Declaration Sebagai Perlindungan Masyarakat Atas Akses Obat Esensial Di Negara Berkembang Pasca Trips Agreement," Jurnal Warmadewa Kertha Wicaksana 14, no. 1 (2020): 56-62, https://doi.org/10.22225/kw.14.1.1585.56-62; Eric M. Solovy and Pavan S. Krishnamurthy, "TRIPS Agreement Flexibilities and Their Limitations: A Response to the UN Secretary-General's High-Level Panel Report on Access to Medicines," George Washington International Law Review 50, no. 1 (2017): 69-124, https://ssrn.com/abstract=2984951.

${ }^{34}$ Gathi, "The Legal Status of the Doha Declaration on TRIPS and Public Health Under the Vienna Convention of the Law of Treaties."

${ }^{35}$ Sharifah Sekalala and Haleema Masud, "Soft Law Possibilities in Global Health Law," Journal of Law, Medicine \& Ethics 49, no. 1 (April 2021): 152-55, https://doi.org/10.1017/jme.2021.20; Solovy and Krishnamurthy, "TRIPS Agreement Flexibilities and Their Limitations: A Response to the UN Secretary-General's High-Level Panel Report on Access to Medicines."

${ }^{36}$ Vita Cita Emia Tarigan and Eka NAM Sihombing, "Kebijakan Pengendalian Pencemaran Di Selat Malaka Yang Bersumber Dari Kecelakaan Kapal," Jurnal Penelitian Hukum De Jure 19, no. 4 (December 2019): 479-502, https://doi.org/10.30641/dejure.2019.V19.479-502; Anthony Aust, Handbook of International Law, 2nd ed. (Cambridge: Cambridge University Press, 2010).

37 Tarigan and Sihombing, "Kebijakan Pengendalian Pencemaran Di Selat Malaka Yang Bersumber Dari Kecelakaan Kapal."

38 Malcolm N. Shaw, International Law, 6th ed. (Cambridge: Cambridge University Press, 2008); David Armstrong, Routledge Handbook of International Law, ed. David Armstrong et al., 1st ed. (New York: Routledge, 2009).

${ }^{39}$ Peter Malanczuk, Akehurst's Modern Introduction to International Law, 7th ed. (New York: Routledge, 2002).

${ }^{40}$ Bart van Klink and Oliver W. Lembcke, "A Fuller Understanding of Legal Validity and Soft Law," in Legal Validity and Soft Law (Berlin: Springer, 2018), 145-64, https://doi.org/10.1007/978-3-319-77522-7_7.

${ }^{41}$ Jaap Hage, "What Is Legal Validity? Lessons from Soft Law," in Legal Validity and Soft Law (Berlin: Cham : Springer International, 2018), 19-45, https://doi.org/10.1007/978-3-319-77522-7_2.
} 
Therefore, informal law such as soft law can support hard law and vice versa in establishing legal order because both are separate entities. ${ }^{42}$

Regardless of the difference of positions about soft law power, all theories agree that soft law influences global legal order either as a trend followed by states or as a separate law by itself. This is why the Doha Declaration has the legitimacy to be followed by states and bring humanist influence towards intellectual property legal regimes, as proven by increasing call and progress towards greater access to medicines for the last twenty years. ${ }^{43}$ The proof of this statement is the cooperation between WHO, WIPO, and WTO to handle public health issues in capacity-building activities and collaborate on matters relating to public health, intellectual property, and trade affairs. ${ }^{44}$

Further progress in the WTO also exists in amendments to the TRIPS Agreement, especially the creation of Article 31bis.1, which allows granting compulsory licenses towards non-domestic entities to produce pharmaceutical products. Article 31 bis. 1 is a boon to Least Developing Countries (LDCs) which often do not have sufficient pharmaceutical infrastructure to produce locally effectively. ${ }^{45}$

\section{Benefits and Issues of Compulsory Licensing Method}

\section{a. Lessons from Previous Use of Compulsory Licensing Method}

Compulsory licensing in the pharmaceutical industry frequently carries enormous legitimacy as a result of the Doha Declaration. However, compulsory licensing has its benefits and consequences. The following paragraphs shall discuss compulsory licensing based on several previous cases after the Doha Declaration to determine the benefits gained and the consequences incurred.

The researcher shall begin with the use of compulsory licensing in Thailand, Brazil, and India perspectives. Thailand issued a compulsory license for Anti-Retroviral Drugs (ARVs) in 2007, including Efavirenz by Merck and Lopinavir/ritonavir and Kaletra by Abbot. This action was furthered in August 2010 where Thailand extended its compulsory licensing over Merck and Abbot ARVs until their patent expiration. ${ }^{46}$

Thailand's motivation to issue compulsory licenses stems from the high percentage of HIV cases in its country. As a comparison, Thailand in 2009 has around 580.000 cases of HIV out of its 66 million population while the United States has around 410.000-880.000 range of HIV cases out of 306 million population, this means HIV infects 1,3\% of Thailand's population. In contrast, the United States percentage is at $0,6 \% .{ }^{47}$ Thailand seeks to reduce drug prices to ensure greater accessibility for its people to measure public health security. However, Thailand still has a problem keeping its prices down despite compulsory licensing measures and international aid drugs. ${ }^{48}$ This raises the specter of Thailand's government's motive being profit rather than public health security.

\footnotetext{
${ }^{42}$ van Klink and Lembcke, "A Fuller Understanding of Legal Validity and Soft Law."

${ }^{43}$ World Trade Organization, Promoting Access to Medical Technologies and Innovation, 2nd Edition, 2nd ed. (Geneva: WTO, 2020), https://doi.org/10.30875/fa323700-en; Haugen, "Does TRIPS (Agreement on Traderelated Aspects of Intellectual Property Rights) Prevent COVID-19 Vaccines as a Global Public Good?"

${ }^{44}$ World Trade Organization, Promoting Access to Medical Technologies and Innovation, 2nd Edition.

45 Urias and Ramani, "Access to Medicines after TRIPS: Is Compulsory Licensing an Effective Mechanism to Lower Drug Prices? A Review of the Existing Evidence."

46 Donald Harris, "TRIPS After Fifteen Years: Success or Failure, as Measured by Compulsory Licensing," Journal of Intellectual Property Law 18, no. 2 (2011): 1-35, https://digitalcommons.law.uga.edu/jipl/vol18/iss2/3. 47 Sheikh Shahnawaz, "The Optimal Timing of Compulsory Licensing: A Story of Thailand's Winter of Discontent," Global Economy Journal 12, no. 4 (November 2012): 1-17, https://doi.org/10.1515/1524-5861.1903.

${ }^{48}$ Kristina M. Lybecker and Elisabeth Fowler, "Compulsory Licensing in Canada and Thailand: Comparing Regimes to Ensure Legitimate Use of the WTO Rules," Journal of Law, Medicine \& Ethics 37, no. 2 (January 2009): 222-39, https://doi.org/10.1111/j.1748-720X.2009.00367.x.
} 
Government Pharmaceutical Organization (GPO), as Thailand state-owned enterprise which manufactured pharmaceutical products, has a history of mark up as high as $1000 \%$ among its $60 \%$ pharmaceutical products that have been sold above-market prices in 2002 . Furthermore, the profits of GPO for 2010 were planned to double that of 2005 profit of 10 billion baths. ${ }^{49}$ These realities question the goals of the Thailand government of keeping down prices by utilizing compulsory licensing, even though at that time Thailand's public health expenditures constitute $10 \%$ of its total government budget and that the funds can be allocated for public health purposes. ${ }^{50}$

Arguments that the inability to further keep down prices was due to supply issue was negated by Thailand government policy of not allowing private manufactures procurement contract, citing compulsory licensing could assure universal coverage. ${ }^{51}$ Especially since Thailand conducts its compulsory licensing based on the grounds of public non-commercial use. ${ }^{52}$ This is further exacerbated with disputed allegations that Thailand does not even seriously negotiate with pharmaceutical manufacturers before issuing compulsory licensing-allegations. This strengthens the evidence that they use compulsory licensing based on the grounds of doubtful public non-commercial in practice. ${ }^{53}$

Overall, there are outcomes about Thailand's HIV/AIDS compulsory licensing. First, although compulsory licensing improved access by lowering prices, Thailand's program brings more benefits to domestic industrial goals than public health benefits. Second, the compulsory licensing implementation brings suspicion towards Thailand's government motive because of allegations that cost-saving from compulsory licensing was geared to profit instead of patients. Third, Thailand's action has gathered international controversy both from private corporations and the government. ${ }^{54}$ Such outcomes resulted in the United States placing Thailand in United States Trade Representatives (USTR) Section 301 report and threatening to remove Thailand from Generalized System of Preferences (GSP) privileges for its lack of transparency, enforcement, and protection. At the same time, Abbott responds by withholding its introduction of new medicines in Thailand. ${ }^{55}$ Unfortunately, such an outcome did not solely affect Thailand but the pro-compulsory licensing world as a whole because retaliation from pharmaceutical companies and the United States have influenced developing countries to restrain in taking advantage of compulsory licensing at that time. ${ }^{56}$

\footnotetext{
${ }^{49}$ Lybecker and Fowler.

${ }^{50}$ Jerome H. Reichman, "Comment: Compulsory Licensing of Patented Pharmaceutical Inventions: Evaluating the Options.," The Journal of Law, Medicine \& Ethics : A Journal of the American Society of Law, Medicine \& Ethics 37, no. 2 (January 2009): 247-63, https://doi.org/10.1111/j.1748-720X.2009.00369.x.

${ }^{51}$ Lybecker and Fowler, "Compulsory Licensing in Canada and Thailand: Comparing Regimes to Ensure Legitimate Use of the WTO Rules."

52 Jamie Feldman, "Compulsory Licenses: The Dangers Behind the Current Practice," Journal of International Business and Law 8, no. 1 (2009): 137-67, https://scholarlycommons.law.hofstra.edu/jibl/vol8/iss1/9/.

${ }^{53}$ Cynthia Ho, "Unveiling Competing Patent Perspectives," Houston Law Review 46, no. 4 (2009): 1047-1114, https://houstonlawreview.org/article/4270-unveiling-competing-patent-perspectives; Lybecker and Fowler, "Compulsory Licensing in Canada and Thailand: Comparing Regimes to Ensure Legitimate Use of the WTO Rules"; Shahnawaz, "The Optimal Timing of Compulsory Licensing: A Story of Thailand's Winter of Discontent." ${ }^{54}$ Lybecker and Fowler, "Compulsory Licensing in Canada and Thailand: Comparing Regimes to Ensure Legitimate Use of the WTO Rules."

${ }^{55}$ Sebastian Haunss and Kenneth Shadlen, "The Politics of Patents: Conditions of Implementation of Public Health Policy in Thailand," in Politics of Intellectual Property: Contestation Over the Ownership, Use, and Control of Knowledge and Information (Cheltenham: Edward Elgar Publishing, 2009), 1-249, https://doi.org/10.4337/9781849802062; Shahnawaz, "The Optimal Timing of Compulsory Licensing: A Story of Thailand's Winter of Discontent"; Harris, "TRIPS After Fifteen Years: Success or Failure, as Measured by Compulsory Licensing"; Reichman, "Comment: Compulsory Licensing of Patented Pharmaceutical Inventions: Evaluating the Options."

${ }^{56}$ Harris, "TRIPS After Fifteen Years: Success or Failure, as Measured by Compulsory Licensing"; Wong, "The Case for Compulsory Licensing during COVID-19."
} 
Unlike Thailand, the Brazilian practice of compulsory licensing is more dynamic. Brazil issued a compulsory license on Efavirenz on May 4, 2007, an HIV/AIDS drug owned by Merck, after previously threatening Merck with compulsory license under public interest (public noncommercial use) if Merck is still persistent in not further reducing its bargaining price ${ }^{57}$ The justification for such action is to save 30 million dollars annually from its HIV/AIDS program, and that previous negotiation with Merck does not reach an agreement. ${ }^{58}$ Merck is displeased with Brazil's actions because it will further set a precedent to encourage the overuse of compulsory licensing methods even for countries that can pay. Brazil action will reduce foreign investment for the pharmaceutical sector, which will impact the introduction of new drugs to Brazil. $^{59}$

Brazil's tendency to persuade pharmaceutical companies to bargain its products with the threat of compulsory license was also shown when Brazil negotiated with Gilead for tenofovir. Because of its previous reputation, Gilead concedes to Brazil by cutting the tenofovir price in half. Brazil's success can be attributed to its strong economic power as the world's 12th largest economy. This status allows Brazil to leverage its pharmaceutical sector in pharmaceutical price negotiations and other trade negotiations. All whilst still being able to cross-retaliate against foreign pressure such as from the United States. ${ }^{60}$ Furthermore, aside from economic power, Brazil employs a mix of soft politics consisting of human rights concerns, the progress of developing countries, international solidarity, and it is another high political-strategic interest. ${ }^{61}$

Unfortunately, Brazil felt the consequences of their method in invoking compulsory licensing when there are damages to patent enforcement and the economy in Brazil. These damages changed the policy of Brazil henceforth to the Point that Brazil did not exercise nor discuss taking compulsory licensing measures in pharmaceutical products. ${ }^{62}$ Brazil's sincerity in its policy change is proven so far as Brazil has yet to be a plan to conduct compulsory licensing nor leverage compulsory licensing to pharmaceutical products. ${ }^{63}$

Last but not least is India which has successfully issued one compulsory license to date. ${ }^{64}$ India has issued a compulsory license to Sorafenib Tosylate (Nexavar), a cancer drug for liver and kidney owned by Bayer, on March 12, 2012. ${ }^{65}$ This compulsory licensing was issued after the Indian Controller General of Patents (Controller) approved the license to Natco Pharma

\footnotetext{
${ }^{57}$ Caio Rodrigues da Silva and Leonor Galvão de Botton, "Compulsory Pharmaceutical Patent Licensing in Brazil: The Controversy of Public Interest," Pharmaceutical Patent Analyst 2, no. 6 (November 2013): 1-3, https://doi.org/10.4155/ppa.13.63; Feldman, "Compulsory Licenses : The Dangers Behind the Current Practice." 58 Vera Zolotaryova, "Are We There Yet? Taking " TRIPS " to Brazil and Expanding Access to HIV / AIDS Medication," Brooklyn Journal of International Law 33, no. 3 (2008): 1099-1126, https://brooklynworks.brooklaw.edu/bjil/vol33/iss3/10.

${ }^{59}$ Feldman, "Compulsory Licenses : The Dangers Behind the Current Practice."

${ }^{60}$ Harris, "TRIPS After Fifteen Years: Success or Failure, as Measured by Compulsory Licensing."

61 Matthew Flynn, "Brazilian Pharmaceutical Diplomacy: Social Democratic Principles versus Soft Power Interests," International Journal of Health Services 43, no. 1 (January 2013): 67-89, https://doi.org/10.2190/HS.43.1.f.

62 Rodrigues da Silva and Galvão de Botton, "Compulsory Pharmaceutical Patent Licensing in Brazil: The Controversy of Public Interest."

63 Medicines Law \& Policy, "The TRIPS Flexibilities Database," Medicines Law \& Policy, 2018, http://tripsflexibilities.medicineslawandpolicy.org/.

64 Reuters Staff, "India Defends Right to Issue Drug 'Compulsory Licenses,"” Reuters, 2016, https://www.reuters.com/article/us-india-patents-usa-idUSKCNOWP0T4; Medicines Law \& Policy, "The TRIPS Flexibilities Database."

${ }^{65}$ Satish Saroha, Deepak Kaushik, and Arun Nanda, "Compulsory Licensing of Drug Products in Developing Countries," Journal of Generic Medicines: The Business Journal for the Generic Medicines Sector 12, no. 3-4 (September 2015): 89-94, https://doi.org/10.1177/1741134313503827; Cinthia Leite Frizzera Borges Bognar, Brittany L. Bychkovsky, and Gilberto de Lima Lopes, "Compulsory Licenses for Cancer Drugs: Does Circumventing Patent Rights Improve Access to Oncology Medications?," Journal of Global Oncology 2, no. 5 (2016): 292-301, https://doi.org/10.1200/jgo.2016.005363.
} 
(Natco) on March 9, 2012. ${ }^{66}$ The rationale for Nexavar compulsory licensing is to increase access to Nexavar drugs by lowering its price from 5000 dollars a month to 170 dollars a month, a $97 \%$ decrease in cost. ${ }^{67}$ The Controller approves the compulsory license because it was previously only accessible to fewer than 200 Indians in 2011 , affordable to only $2 \%$ of all patients with kidney and liver cancers. ${ }^{68}$ This is contrary to Section 84 of Indian Patent Law which allows compulsory licensing for patents that are not available and affordable to the public at a reasonable price. ${ }^{69}$

A decisive factor favoring Natco is Bayer's defense arguing an alternative to Nexavar already existed in India made by CIPLA at a far cheaper price, a company which Bayer is already in the process of litigating due to allegations of Nexavar patent infringement in Mumbai. ${ }^{70}$ The compulsory licensing decision then was challenged by Bayer to the Indian Patent Appellate Board (IPAB). Still, it was rejected on March 4, 2013. The IPAB upheld the Controller's decision but increased the royalty payable to Bayer from $6 \%$ to $7 \%$ so that Bayer will derive a good advantage from its patent according to Section 90 (2) of Indian Patent Law. ${ }^{71}$

Unsurprisingly, the United States reacted somewhat strongly to the decision. According to Access Campaign-a part of Medicins Sans Frontières (MSF), the United States Commerce Secretary, John Bryson has raised concerns about the dilution of the Indian patent regime. Then on June 27, 2012, there were talks in the United States House of Representatives that the Indian compulsory licensing decision was a TRIPS Agreement violation. On February 21, 2013, this got worse when the Global Intellectual Property Center (GIPC) ranked India the lowest of eleven countries in IP rights strength. This is followed by further escalation of statements in the next month against Indian patent law as testimonies and lobbying efforts further the United States frustration. ${ }^{72}$

Based on Thailand, Brazil, and India cases, there are benefits and Issues gained from the issuance of compulsory licensing. On the one hand, all three countries have a varying degree of success in improving access and affordability of medicines due to compulsory licensing. On the other hand, compulsory licensing could be alleged as a mask to fulfill industrial objectives rather than humanitarian ones, as happened in the Thailand case. In Thailand, it is a geopolitical tool of intimidation under Brazil's case or invites the unwanted retaliation from the United States as what happened to all three countries. There is no doubt that compulsory licensing issuance would invite pressure that can damage the state economy. However, as in the case of India, countries with robust patent regimes and economies will be able to maximize the benefits of compulsory licensing while defending against the consequences.

\section{b. Treaty Performance Regarding Compulsory Licensing Invocation Under TRIPS Agreement}

After the Doha Declaration, what constitutes a good-faith interpretation for TRIPS Agreement performance are interpretations following objectives and principles in Articles 7 and 8, respectively, with particular emphasis on Article 7 as an expression of good faith

\footnotetext{
${ }^{66}$ Mansi Sood, "Natco Pharma Ltd. v. Bayer Corporation and the Compulsory Licensing Regime in India," NUJS Law Review 6, no. 1 (2013): 99-119, http://nujslawreview.org/2016/12/02/natco-pharma-ltd-v-bayer-corporationand-the-compulsory-licensing-regime-in-india/.

${ }^{67}$ Bela Gandhi, "India's Compulsory License Model: Increased Pharmaceutical Access and Innovation Coexist," BYU Prelaw Review 33, no. 5 (2019): 33-51, https://scholarsarchive.byu.edu/byuplr/vol33/iss1/5/.

${ }^{68}$ Saroha, Kaushik, and Nanda, "Compulsory Licensing of Drug Products in Developing Countries."

${ }^{69}$ Gandhi, "India's Compulsory License Model: Increased Pharmaceutical Access and Innovation Coexist."

${ }^{70}$ Saroha, Kaushik, and Nanda, "Compulsory Licensing of Drug Products in Developing Countries."

${ }^{71}$ Sood, "Natco Pharma Ltd. v. Bayer Corporation and the Compulsory Licensing Regime in India."

72 Médecins Sans Frontières, "A Timeline of US Attacks on India's Patent Law and Generic Competition" (Geneva, 2015), https://msfaccess.org/sites/default/files/2018-10/IP_Timeline_US pressure on India_Sep 2014_0.pdf.
} 
principle. ${ }^{73}$ The good faith principle also has been expanded in cases following the TRIPS Agreement.

First, The Russia-Transit case states that GATT 1994 and, by extension, the TRIPS Agreement clarifies good faith as taking measures that do not circumvent treaty obligations. ${ }^{74}$ This is further clarified in the Saudi Arabia-IPR case, where Saudi Arabia did an example of circumvention. By denying Intellectual Property criminal proceedings as a remedy, Saudi Arabia violates Article 61 of the TRIPS Agreement. ${ }^{75}$

Second, to be interpreted in good faith, and interpretation must be effective in the sense that the interpretation must not result in whole clauses or treaty paragraphs to redundancy. This is founded under Article 31 of VCLT 1969, which interpretation must be based upon treaty text. $^{76}$ This is further explained in United States-Section 211 case where the Appellate report states relevant provisions must be included in the interpretation to be practical. ${ }^{77}$ Ignoring or failing to interpret TRIPS provisions adequately indicates that the interpretation was not made in good faith. ${ }^{78}$ An example of this exists in the Canada-Pharmaceutical case, where the Panel recognizes that Article 30 of TRIPS is limited by Article 7 and 8.1 of TRIPS. This is one of the earliest recognitions of Article 7 and 8 TRIPS Agreement scope before the Doha Declaration. ${ }^{79}$

Third, the abuse of correct doctrine within the good faith principle. This means the interpretation of the TRIPS Agreement must not be something that degrades treaty obligations and devalue other members' treaty rights. This is confirmed in the US-Shrimp case, where abuse or misuse of rights will negate the treaty rights of other members ${ }^{80}$ Hence, according to the US-Shrimp case lead, Article 7 objectives are subsequently used as a balancing tool between TRIPS rights and obligations. ${ }^{81}$

Fourth, legitimate expectations. In the India-Patents case, there is a legitimate expectation of protection over security and predictability in the multilateral trading system. However, India fails to meet this legitimate expectation due to its mailbox system inadequacy in ensuring equal competition between foreign and domestic businesses. ${ }^{82}$ From this decision, the impact upon TRIPS Agreement is the recognition of legitimate expectation for market access and reciprocal trade benefits in performing good faith. ${ }^{83}$

From these cases, there are four elements of good faith in the TRIPS Agreement based on cases. (1) Measures or interpretation must not circumvent treaty obligations; (2) Measures or interpretation must be effective in the sense of not ignoring or underrepresenting other relevant clauses; (3) Interpretation or measures must not be abusive, in the sense of degrading other

\footnotetext{
${ }^{73}$ Slade, "Good Faith and the TRIPS Agreement: Putting Flesh on the Bones of the TRIPS 'Objectives."”

${ }^{74}$ Stephanie Hartmann, "Russia - Measures Concerning Traffic in Transit (WTO)," International Legal Materials 58, no. 5 (October 2019): 899-1027, https://doi.org/10.1017/ilm.2019.40.

${ }^{75}$ WTO Panel, Saudi Arabia - Measures Concerning the Protection of Intellectual Property Rights (2018).

${ }^{76}$ WTO Appellate Body, Japan - Taxes on Alcoholic Beverages (1996).

77 Robert Howse and Damien J. Neven, "United States - Section 211 Omnibus Appropriations Act of 1998 (WT/DS176): Report of the Appellate Body," in Dispute Settlement Reports 2002, ed. World Trade Organization (Cambridge: Cambridge University Press, 2004), 589-682, https://doi.org/10.1017/9781108379052.001.

${ }^{78}$ Slade, "Good Faith and the TRIPS Agreement: Putting Flesh on the Bones of the TRIPS 'Objectives."

${ }^{79}$ World Trade Organization, "Canada - Patent Protection of Pharmaceutical Products (WT/DS114) Report of the Panel," in Dispute Settlement Reports 2000 (Cambridge: Cambridge University Press, 2002), 2289-2582, https://doi.org/10.1017/9781108378840.002.

${ }^{80}$ World Trade Organization Appellate Body, "United States - Import Prohibition of Certain Shrimp and Shrimp Products (WT/DS58): Report of the Appellate Body," in Dispute Settlement Reports 1998, ed. World Trade Organization (Cambridge: Cambridge University Press, 2001), 2755-2820, https://doi.org/10.1017/9781108378703.001.

${ }^{81}$ Slade, "Good Faith and the TRIPS Agreement: Putting Flesh on the Bones of the TRIPS 'Objectives."

${ }^{82}$ World Trade Organization, "India - Patent Protection for Pharmaceutical and Agricultural Chemical Products (WT/DS79/R): Report of the Panel," in Dispute Settlement Reports 1998 (Cambridge: Cambridge University Press, 2001), 2661-2752, https://doi.org/10.1017/9781108378697.002.

${ }^{83}$ Slade, "Good Faith and the TRIPS Agreement: Putting Flesh on the Bones of the TRIPS 'Objectives."”
} 
members treaty rights; (4) Interpretations and measures must ensure equal competition between foreign and domestic businesses.

The benefits and issues about compulsory licensing gave rise to various legal arguments about the scope of compulsory licensing under Article 31. As the TRIPS provision under Article 31 does not explicitly protect cases of retaliatory action against less powerful states to deter them from using compulsory licensing, compulsory licensing is used as a tool of intimidation against pharmaceutical actors for states to gain a better price. Therefore, this section will determine whether the actions of Thailand, Brazil, India, and the United States conform to the principle of pacta sunt servanda and good faith regarding conformity with the TRIPS Agreement.

Article 26 of the VCLT incorporates the old international customary law of pacta sunt servanda (rooted in private law relations) to treaty law. Pacta sunt servanda itself means that agreements must be kept. The full excerpt of Article 26 is "Every treaty in force is binding upon the parties to it and must be performed by them in good faith". From this excerpt could be inferred that five elements are arising from the Article: (1) Every treaty; (2) in force; (3) Legally binding force; (4) Duty to perform; and (5) Compliance. ${ }^{84}$

For these paragraphs, the researcher shall review the duty to perform against previous case examples starting from Thailand. For the duty to good faith performance, this is not so clear because of profit motivation by GPO and that Thailand does not allow procurement contracts for the private pharmaceutical sector by citing that greater access would be better achieved in government hands. The monopoly of production by GPO and profit motivation could be argued respectively that GPO sole production would negate distribution hurdles. These distributions were prevalent in Thailand's private pharmaceutical sector at that time, and that profits gained by GPO could be used as funds for public health programs in Thailand, and therefore still comply with public non-commercial purposes. For the good faith in interpretation, this is clear. Thailand has implemented the provisions of the TRIPS Agreement correctly under Article 31 (b) under the public non-commercial clause by informing the patent owners as both Abbot and Merck do not dispute this. So far, there is no complaint about adequate remuneration by both patent holders; thus, this further strengthens the duty to perform in Thailand's case. There is no circumvention of treaty obligations by Thailand.

For the object and purposes of the treaty, a review can be derived from Article 7 "objectives" and Article 8 "principles" of the TRIPS Agreement. The Doha Declaration provision Article 5 (a) requires for "...each provision of the TRIPS Agreement shall be read in light of the object and purpose of the Agreement as expressed, in particular, its objectives and principles". It has been a scholarly consensus to refer towards Article 7 and Article 8 of the TRIPS Agreement to find its object and purpose, owing to the Doha Declaration influence that sets public health as a legitimate interest recognized and accommodated by the TRIPS Agreement. ${ }^{85}$ Hence, there is no circumvention or ignoring of relevant clauses in this case.

Article 7 of the TRIPS Agreement requires a middle ground between producers and consumers in optimizing innovation, promoting social and economic development whilst cushioning detrimental consequences of intellectual property protection. ${ }^{86}$ Article 8.1 of the TRIPS Agreement further allows member states to adopt measures to protect public health and the public interest by formulating and amending their laws and regulations without prejudice to

\footnotetext{
${ }^{84}$ Oliver Dörr and Kirsten Schmalenbach, "Article 26 Pacta Sunt Servanda," in Vienna Convention on the Law of Treaties: A Commentary, ed. Oliver Dörr and Kirsten Schmalenbach (Berlin, Heidelberg: Springer Berlin Heidelberg, 2012), 1-1423, https://doi.org/10.1007/978-3-642-19291-3.

85 Alice Maxwell, "Plainly Justifiable? The World Trade Organization's Ruling on the Validity of Australia's 'Plain Packaging' Under Article 20 of the TRIPS Agreement," Asian Journal of WTO \& International Health Law \& Policy 14, no. 1 (2019): 115-45, https://doi.org/10.2139/ssrn.3363052.

${ }^{86}$ Alison Slade, "The Objectives and Principles of the WTO TRIPS Agreement: A Detailed Anatomy," Osgoode Hall Law Journal 53, no. 3 (2016): 1-59, https://ssrn.com/abstract=2781664.
} 
other articles in the TRIPS Agreement. The excerpt balances this provision in Article 8.2, which prohibits the abuse of rights holders' rights and practices that restrain trade. ${ }^{87}$

Thailand's actions fulfillment of Article 7 is disputed here. It can be argued that Thailand could do more to lessen compulsory licensing on the patent holders. During the compulsory licensing case, Thailand was governed by a military junta ${ }^{88}$. That government raised its defense budget to 30 billion dollars. Therefore, lacked funds to cope with the HIV crisis without compulsory licensing, even as its status as the $34^{\text {th }}$ biggest economy at that time. Furthermore, the GPO was historically corrupt in its practice. Its facilities did not meet WHO standards, thus will not be as effective as if the original patent holders produce it. Nevertheless, it is essential to keep in mind as a mitigating fact that the pharmaceutical sector was less than $0.5 \%$ in the global market at that time, and thus its effects should not be decisive to the patent holders. ${ }^{89}$ It can be argued that Thailand's exercise of compulsory licensing is abusive to the patent holder's rights.

For Article 8.1, Thailand did have laws and regulations about compulsory licensing in Section 51 of the Patent Act of BE 2522, which allows compulsory licensing in "...service for public consumption or which is of vital importance to the defense of the country, or for the preservation or realization of natural resources or the environment, or to prevent or relieve a severe shortage of food, drugs, or other consumption items, or for any other public service...". 90 While not abusing rights and conduct practices that could restrain trade in Article 8.2. Thailand did not such thing because of its relatively high percentage of HIV patients. Thailand uses a long-established law to justify its compulsory licensing, which nobody complains about that restricts trade. This means Thailand has ensured that it satisfied legitimate expectations.

Brazil's case is different from Thailand, where it has been established that Brazil uses compulsory licensing threat persuade patent holders in price negotiation. However, it is important to note that during the period from 2002 to 2011, there are around 530.000 people with HIV in Brazil, in which 253.706 deaths were reported, and there are 20.2 cases of HIV/AIDS per 100.000 people, all of which signifies the existence of HIV/AIDS pandemic in Brazil. Furthermore, as leverage against United States actions and using the US-Brazil dispute over cotton subsidies, Brazil enacted Provisional Measure 482/2010 on February 10, 2010, which consists of measures against intellectual property rights as retaliation under WTO DSU. ${ }^{91}$ Brazil measure here is similar to what Russia has done in the Russia-Transit case years later. Both states here made sure that none of their measures circumvented treaty obligations. ${ }^{92}$

About the duty to good faith in treaty performance, there is quite a question whether pressures of compulsory licensing can be used to intimidate patent holders into lowering their negotiating prices. This bears in mind that Brazil is the $12^{\text {th }}$ biggest economy at compulsory licensing and thus has more leverage and buying power than Thailand. Nevertheless, Brazil negotiated with patent holders despite Article 31 (b) of the TRIPS Agreement not requiring it for public non-commercial use. Furthermore, unlike Thailand's case, the negotiation between Brazil and the patent holders began in earnest as both have evidence in negotiating prices. ${ }^{93}$

\footnotetext{
87 Taubman, Wager, and Watal, “Agreement on Trade-Related Aspects of Intellectual Property Rights (TRIPS Agreement) (as Amended on 23 January 2017)."

${ }^{88}$ A military junta is a government led by a committee of military leaders.

${ }^{89}$ Ho, "Unveiling Competing Patent Perspectives."

${ }^{90}$ Sakda Thanitcul and Matthew Lim Braslow, "Compulsory Licensing of Chronic Disease Pharmaceuticals in Thailand," Thai Journal of Pharmaceutical Sciences 37, no. 2 (2013): 61-83, https://www.researchgate.net/publication/289551723_Compulsory_licensing_of_chronic_disease_pharmaceutica ls_in_Thailand.

${ }^{91}$ Viviane Yumy Mitsuuchi Kunisawa, "Analyzing the Brazil Case," in The TRIPS Agreement Implementation in Brazil, ed. Christoph Ann et al., 1st ed. (Baden-Baden: Nomos Verlagsgesellschaft mbH, 2015), 151-78.

${ }^{92}$ Hartmann, "Russia - Measures Concerning Traffic in Transit (WTO)."

${ }^{93}$ Wong, "The Case for Compulsory Licensing during COVID-19."
} 
This can be seen as Brazil's act of good faith in domestic performance and can be extended to good faith in interpretation because both sides have not claimed that either side interprets the TRIPS Agreement unreasonably. Here, Brazil took a step forward by complying with Article 31 (b) of TRIPS as a precaution, showing its considerations for relevant clauses.

For the duty not to defeat the object and purpose of the treaty, it can be argued that Brazil should not abuse the threat of compulsory licensing in its negotiation, even though such a technique did produce a result. However, will Brazil get the same bargained price and deal decisively with the HIV pandemic if Brazil takes the softer approach? Perhaps this might be possible with Brazil's economic power and that it did not suffer from the same domestic condition as Thailand. This could potentially be a reason for the abuse of rights conducted by Brazil in using the threat of compulsory licensing in negotiation.

However, there is no decisive complaint on the capability of Brazil to balance patent holder and consumer rights to medicine. Brazil did suffer the consequences of its policy in terms of economy and patent enforcement and has refrained from using a compulsory license as a pressure tool in further negotiations. Furthermore, Brazil did have compulsory licensing law in its Law No. 9.279 of May 14, 1996-amended in 2001 (Law on Industrial Property), which serves as a basis for compulsory licensing for pharmaceutical products. Therefore Brazil's fulfillment of the TRIPS Agreement object and purposes is evidence of its compliance to duty not to defeat the object and purpose of the treaty. ${ }^{94}$ Since patent holders have no complaint about this law, Brazil has satisfied legitimate expectations in ensuring equal competition.

For the case of India, there is no doubt about India's compliance to both good faith in performance and good faith in interpretation because of the rigidity of Indian patent courts and the implementation of a strong intellectual property regime in India's domestic patent law. There is no doubt on the object and purpose of the treaty since it has been established that previous access to cancer drugs in India was so low that only $2 \%$ of Indians can access it. Furthermore, compulsory licensing is not so easily implemented in India, as it takes years before the compulsory licensing decision is final (from 2011 to 2013 in Bayer's case). Bayer did get more royalty at $7 \%$ as a result of the IPAB decision.

India gives the patent holder its right to more significant royalty and equal competition between foreign and domestic businesses. Both domestic and foreign businesses have the same recourse for compulsory licensing remedies. All of this also satisfies good faith in TRIPS provisions due to India's adherence to not circumvent treaty obligations, not ignoring or underrepresenting other relevant clauses, not being abusive, in the sense of degrading other members' treaty rights as shown by India.

Now on to the actions of the United States, it can be argued that the United States' pressure tactics against countries that implement compulsory licensing be contrary to the duty to perform the TRIPS Agreement. On duty to perform in good faith, the United States conducts pressure measures to Thailand, Brazil, and India. Its aggressive reprisal measures are contrary to Article 23 of Annex 2, where the United States should instead file a claim against the parties, which is viewed as wrongful in the use of compulsory licensing. ${ }^{95}$ For the good faith in interpretation, the United States did not claim absurd nor unreasonable interpretation, and therefore this will not be discussed.

For the objective and purpose of the TRIPS Agreement, it can be seen from the United States actions that it did not act entirely in the spirit of Article 7 of the TRIPS Agreement due to its retaliatory actions. These actions hamper the capability and legitimacy of foreign governments in formulating their pharmaceutical policies that balance the interest between patent holders and consumers. However, it can be argued that the United States is using its power to protect the patent holders from being abused under Article 8.2 of the TRIPS

\footnotetext{
${ }^{94}$ Kunisawa, "Analyzing the Brazil Case."

${ }^{95}$ Reichman, "Comment: Compulsory Licensing of Patented Pharmaceutical Inventions: Evaluating the Options."
} 
Agreement, even though their measures are left much to be desired. Based on cases and their applicability to VCLT 1969 regarding good faith in treaty performance, there are occasions that actions of Thailand, Brazil, and the United States are not necessarily fully compliant. This means similar cases could be expected to happen when an effective patented COVID-19 drug enters the pharmaceutical market. ${ }^{96}$

\section{Possible International and Local Remedies Against Compulsory Licensing}

\section{a. International Remedies}

From previous cases, there have been examples in which patent holders fought against compulsory licensing. The researcher will briefly explain the options available for patent holders in accessing international remedies starting from litigation before delving into other methods of gaining international remedies. On accessing remedies by litigation measures aside from DSU, the multinational patent holders mostly prefer international investment arbitration under bilateral investment treaties. This use of international investment arbitration uses a loophole in which the DSU did have exclusive jurisdiction in dispute between states. Still, it said nothing about a state dispute with a non-state party. The international investment arbitration also could have a chilling effect on the compulsory licensing granted by government authorities. This method is so effective that a simple threat of using the Investor-State Dispute Settlement (ISDS) mechanism with significant compensation could refrain countries from enacting compulsory licensing measures. ${ }^{97}$

Unfortunately, no compulsory licensing cases are concluded within the international forum or at least those known to the public. The closest case is the Brazil - Patent Protection in 2001 and Argentina - Certain Measures on the Protection of Patents and Test Data 2002, which end in a mutually agreed solution instead of proceedings. ${ }^{98}$ The case is different for the ISDS mechanism.

Some Investment Agreements (IAs) such as India-Singapore FTA and Australia-Uruguay BIT exclude the issuance of compulsory licensing from the scope of expropriation. ${ }^{99}$ Investors could still sue the states against compulsory licensing by using the Fair and Equitable Treatment (FET) clause and the national treatment clause. This could be done by alleging that the exercise of compulsory licensing was founded on unstable regulation made due to trends in COVID$19,{ }^{100}$ or that the exercise of compulsory licensing is discriminately targeted to a foreign company. ${ }^{101}$ Alternatively, investors could use the ISDS mechanism to force states into

\footnotetext{
${ }^{96}$ Wong, "The Case for Compulsory Licensing during COVID-19."

${ }^{97}$ Katarzyna Kaszubska, “Compulsory Licensing under India’s New Model Bilateral Investment Treaty,” Review of Market Integration 9, no. 3 (December 2017): 139-54, https://doi.org/10.1177/0974929217744466.

${ }^{98}$ Emmanuel Kolawole Oke, "The Incorporation of a Right to Health Perspective into Brazil's Patent Law Reform Process," in Law and Policy in Latin America, ed. Pedro Fortes et al. (London: Palgrave Macmillan UK, 2017), 311-26, https://doi.org/10.1057/978-1-137-56694-2; Letícia Frazão Leme, "Flexibilities Under Article 39.3 of the TRIPS Agreement: Protection of Pharmaceutical Test Data and the Case of Brazil," in The WTO Dispute Settlement Mechanism, ed. Alberto do Amaral Júnior, Luciana Maria de Oliveira Sá Pires, and Cristiane Lucena Carneiro (Cham: Springer International Publishing, 2019), 339-55, https://doi.org/10.1007/978-3-030-03263$0 \_22$.

${ }^{99}$ Prabhash Ranjan, "Compulsory Licences and ISDS in Covid-19 Times: Relevance of the New Indian Investment Treaty Practice," Journal of Intellectual Property Law \& Practice 16, no. 7 (2021): 748-59, https://doi.org/10.1093/jiplp/jpab084.

${ }^{100}$ Federico Ortino, "The Obligation of Regulatory Stability in the Fair and Equitable Treatment Standard: How Far Have We Come?," Journal of International Economic Law 21, no. 4 (December 2018): 845-65, https://doi.org/10.1093/jiel/jgy039.

${ }^{101}$ Yamashita Tomoko, "Procedural and Normative Competition between the WTO's Dispute Settlement and the Investor-State Arbitration: Focusing on the National," Public Policy Review 16, no. 5 (2020): 1-23, https://www.mof.go.jp/english/pri/publication/pp_review/ppr16_05_09.pdf.
} 
lobbying against compulsory licensing. This approach, unfortunately, is riddled with ethical issues. ${ }^{102}$

Non-litigation measures, on the other hand, can be done by relying upon the patent holder's flag state mechanism, such as the USTR Section 301 Report from the United States. The USTR Section 301 Report annually examines the United States trade partners' intellectual property regime and classifies problematic countries into three watch lists. ${ }^{103}$ Countries that are classified as "Priority Foreign Country" will trigger sanction proceedings initiated by the USTR, ${ }^{104}$ These sanctions happen even when such proceedings are legally questionable under Article 23.2 of Annex 2. ${ }^{105}$ However, this method is only effective for countries with less economic strength and could only offer cold comfort because there is no guarantee of reparations. Another nonlitigation measure is to settle after the initiation of WTO DSU proceedings. From examples of Brazil - Patent Protection in 2001 and Argentina - Certain Measures on the Protection of Patents and Test Data 2002, WTO DSU litigation could be used to force the parties to consider settlement agreement instead of continuing the proceedings.

\section{b. Domestic Remedies}

This section will elaborate on the domestic mechanism taken by claiming parties against TRIPS Compulsory Licensing invocation. Aside from generic methods, the researcher will explain about constitutional review mechanism as a theoretical measure to claim remedies against compulsory licensing, mainly by ex-post review, and how this could be an option for claimants.

One of the first steps in domestic measures against compulsory licensing is to prevent compulsory licensing from happening. This can be seen in negotiation between patent owners and governments or generic manufacturers such as Natco in India's case, even though negotiation is not compulsory for public non-commercial purposes and national emergencies under the TRIPS Agreement Article 31 (b). ${ }^{106}$ Depending on the relative economic and political power of the state, negotiations can result in either triumphant voluntary licensing in place of compulsory licensing, ${ }^{107}$ Compulsory licensing results in harmful consequences for states such as in Thailand and Brazil cases, and successful compulsory licensing such as in India.

When negotiations did not work, patent holders could take measures against the compulsory licensing decision by filing a suit in state courts. Results may vary based on each state's patent regime. Thailand's patent law (Patent Act BE 2522, sections 50 and 51) did not allow for patent holders to contest government use of compulsory licensing for the public noncommercial use. A court remedy by the Board of Patents and further appeal by the International

\footnotetext{
102 Public Eye, "Compulsory Licensing in Colombia: Leaked Documents Show Aggressive Lobbying by Novartis," Public Eye, 2017, https://www.publiceye.ch/en/media-corner/press-releases/detail/compulsorylicensing-in-colombia-leaked-documents-show-aggressive-lobbying-by-novartis.

103 Aswathy Asok, "Compulsory Licensing for Public Health and Usa's Special 301 Pressure: An Indian Experience," Journal of Intellectual Property Rights 24, no. 5-6 (2019): 125-31, http://nopr.niscair.res.in/handle/123456789/54321.

${ }^{104}$ Suma Athreye, Lucia Piscitello, and Kenneth C. Shadlen, "Twenty-Five Years since TRIPS: Patent Policy and International Business," Journal of International Business Policy 3, no. 4 (2020): 315-28, https://doi.org/10.1057/s42214-020-00079-1.

105 Reichman, "Comment: Compulsory Licensing of Patented Pharmaceutical Inventions: Evaluating the Options."; Asok, "Compulsory Licensing for Public Health and Usa's Special 301 Pressure: An Indian Experience."

${ }^{106}$ Taubman, Wager, and Watal, “Agreement on Trade-Related Aspects of Intellectual Property Rights (TRIPS Agreement) (as Amended on 23 January 2017)."

107 Bryony Simmons, Graham S. Cooke, and Marisa Miraldo, "Effect of Voluntary Licences for Hepatitis C Medicines on Access to Treatment: A Difference-in-Differences Analysis," The Lancet Global Health 7, no. 9 (2019): 1189-96, https://doi.org/10.1016/S2214-109X(19)30266-9.
} 
Trade Court could only be filed to contest compulsory licensing conditions and matters about patent royalty. ${ }^{108}$

Brazilian regulates compulsory licensing in Law No. 9.279 of May 14, 1996-amended in 2001 (Law on Industrial Property) in which compulsory licensing is regulated under Section III Article 68-74. ${ }^{109}$ Brazilian Law on Industrial Property allows the patent holder to contest compulsory licensing filing by the generic company within sixty days after an application has been published by the National Institute of Industrial Property (INPI). ${ }^{110}$ The patent holders could contest the INPI decision should a compulsory license be granted under Article 73 (7), but such appeal does not suspend the compulsory licensing decision. ${ }^{111}$ Appeals to the compulsory licensing decision can be pursued in Brazil Federal Trial Court and could be appealed until it reached Federal Supreme Court. ${ }^{112}$

India is perhaps one of the most robust compulsory licensing regimes, as shown in the Bayer case. India has its structure for patent-related disputes like Thailand in the Controller for the first instance and IPAB for appeals. However, unlike its Thailand counterparts, India allows patent holders to challenge the compulsory licensing decision. Furthermore, in its decision, IPAB has shown to be fairer for patent holders, as shown when IPAB grants additional royalty to give a reasonable advantage to Bayer in its compulsory licensing. ${ }^{113}$

Aside from patent or regular court litigation, a theoretical possibility for compulsory licensing can happen in the constitutional court. Ex-post treaty review is a constitutional review that examines the constitutionality of treaty provision to state constitution after the treaty has been concluded. ${ }^{114}$ Patent holders could submit a constitutional petition that a particular interpretation of the TRIPS Agreement which mandates the issuance of the compulsory license, is contrary to the state's constitutional provision.

Indonesia has conducted a similar review about ASEAN Charter constitutionality under Constitutional Court Decision No. 33/PUU-IX/2011. The ASEAN Charter is transformed to national law under Law No. 38/2008 on the Ratification of the ASEAN Charter; hence, the basis on which the constitutional court can justify its review of ASEAN Charter content. Further reasoning by the constitutional court in its authority to review the ASEAN Charter is that Indonesia's sovereignty allows the Charter to be made in the first place. Indonesia has the complete freedom to bind and release itself from treaties, and that Indonesia has the right to review its participation in international treaties. ${ }^{115}$

The outcome of the Constitutional Court Decision No. 33/PUU-IX/2011 is the conformity of the ASEAN Charter under the Indonesian constitution, had the constitutional court decided otherwise, two outcomes could be pursued. First, weak-form review, which is legally non-

\footnotetext{
108 Jakkrit Kuanpoth, "Compulsory Licences: Law and Practice in Thailand," in Compulsory Licensing Practical Experiences and Ways Forward, ed. Reto M. Hilty and Kung-Chung Liu (Berlin: Springer Berlin Heidelberg, 2015), 61-77, https://doi.org/10.1007/978-3-642-54704-1_4.

${ }^{109}$ Milton Lucídio Leão Barcellos, “Compulsory License in Brazil: Competition Tool or Just a Threat?," Revista de Propriedade Intelectual - Direito Constitucional e Contemporâneo 10, no. 3 (October 2016): 141-52, https://doi.org/10.16928/2316-8080.V10N3p.141-152.

${ }^{110}$ Rodrigues da Silva and Galvão de Botton, "Compulsory Pharmaceutical Patent Licensing in Brazil: The Controversy of Public Interest."

111 Licks Attorneys, "Brazilian Patent Statute and Selected Patent Prosecution Rules" (2016), http://static.lickslegal.com/pdf/Licks Attorneys - Brazil - Selected Patent Prosecution Rules.pdf?x54306.

${ }^{112}$ Kunisawa, "Analyzing the Brazil Case."

113 Sood, "Natco Pharma Ltd. v. Bayer Corporation and the Compulsory Licensing Regime in India."

114 Mario Mendez, "Constitutional Review of Treaties: Lessons for Comparative Constitutional Design and Practice," International Journal of Constitutional Law 15, no. 1 (January 2017): 84-109, https://doi.org/10.1093/icon/mox004.

115 Januari Sihotang, "Peran Mahkamah Konstitusi Sebagai Lembaga Penguji Undang-Undang Dalam Masyarakat Ekonomi ASEAN," Dialogia Iuridica: Jurnal Hukum Bisnis Dan Investasi 7, no. 1 (2017): 37, https://doi.org/10.28932/di.v7i1.707.
} 
binding, means the constitutional court will state that the ASEAN Charter is unconstitutional. Therefore the current executive government must solve the problem, but without legal consequences for the central government. Second, a strong-form review means that the constitutional court could legally compel the executive government to either renegotiate the treaty to conform to the constitutional court decision or withdraw entirely lawfully. ${ }^{116}$ However, in case of nonconformity, Indonesia does not have a law that expressly granted its constitutional court to legally compel the executive branch to renegotiate or withdraw from a treaty. Therefore a weak-form review outcome would be most likely to happen.

Indonesia is not the only country that could legally put its treaties to the constitutional court. Countries such as Germany, Hungary, and Italy could legally conduct a constitutional review of their treaties. ${ }^{117}$ This is an unexplored opportunity for patent holders to try constitutional review against compulsory licensing issuance. However, it is important to consider that depending on the state. This approach does not have a compensation guarantee if the compulsory licensing decision does not have a suspensive effect. Therefore, the constitutional review can potentially affect post-review attempts of compulsory licensing and not the decision submitted for constitutional review.

\section{Conclusion}

Compulsory licensing will be a significant issue during this COVID-19 pandemic due to humanitarian reasons, and pharmaceutical patents that are proven as an effective drug against COVID-19 will likely face compulsory licensing. However, previous cases of compulsory licensing have shown that not all states practice the TRIPS Agreement dutifully and under VCLT 1969, that invoking compulsory licensing would most likely invite retaliation from the patent holder's flag state even though the TRIPS Agreement has seen more humanitarian interpretation since the Doha Declaration.

From the discussion, there are four fundamental requirements to perform the TRIPS Agreement in good faith. (1) Measures or interpretation must not circumvent treaty obligations; (2) Measures or interpretation must be effective in the sense of not ignoring or underrepresenting other relevant clauses; (3) Interpretation or measures must not be abusive, in the sense of degrading other members treaty rights; (4) interpretations and measures must ensure equal competition between foreign and domestic businesses.

Therefore, access to remedies against compulsory licensing is paramount for patent holders. Legal remedies can be gained in international and domestic means. Internationally, the DSU mechanism seems to be the preferred method to resolve compulsory licensing disputes. However, the plaintiff state often uses such measures to pressure a negotiated settlement instead of resolution by DSU proceedings. Hence indicators to determine good faith in TRIPS Agreement performance and interpretation about compulsory licensing are derived from loosely relevant decisions. The same strategy was also used in ISDS proceedings. Alternatively, plaintiffs could negotiate with states that invoke compulsory licensing and take advantage of the USTR Section 301 mechanism in the case of the USA being the plaintiff's flag state. A drawback of international litigation is the cost factor. Therefore, for matters such as compulsory licensing, parties prefer negotiation.

In domestic scope, plaintiffs usually claim remedies by filing a lawsuit. This works well for countries that have robust patent regimes, both for states and the plaintiff. Before litigation, the parties conduct negotiations. The purpose of negotiation is to ensure a possibility of voluntary licensing by the patent holder. A voluntary licensing mechanism places more autonomy on patent holders instead of price-determination by the state in compulsory licensing.

\footnotetext{
${ }^{116}$ Mendez, "Constitutional Review of Treaties: Lessons for Comparative Constitutional Design and Practice."

${ }^{117}$ Noor Sidharta et al., "Judicial Preview on the Bill on International Treaty Ratification," Constitutional Review 3, no. 1 (August 2017): 24-42, https://doi.org/10.31078/consrev312.
} 
Aside from regular negotiations and litigations, it is unfortunate that constitutional review of treaties possibility is still unexplored in this matter. It is hoped that this constitutional review of treaties would soon debut when COVID-19 effective drug has been released. Until such an occasion has happened, this discussion would remain a theoretical possibility. A more present matter would be the need for strengthening the compulsory licensing regime for states. A constitutional review of treaties regarding compulsory licensing decisions would develop the intersection between constitutional law and international law in aspects of intellectual property.

As this research has shown in the case of India, a robust patent regime-particularly in compulsory licensing would increase the odds of resilience against retaliation from the patent holder's state. India managed to resist the United States' probing over their patent regime through their robust legal regime of patents aside from their economic might, hence even though Bayer's case's decision still favors Natco. There is no mass retaliation like what happened with Brazil and Thailand. A robust patent regime guarantees legal certainty, strengthening foreign investors' confidence in doing business despite a case against their interest. This is an important lesson to be replicated by other countries, including Indonesia. The researcher shall conclude that this research is still limited as this article only examines the United States as the patent holder's flag state. Further research focusing on the patent holder with the equivalent power would be needed to understand compulsory licensing dynamics further.

\section{REFERENCES}

Abbott, Frederick M. "The TRIPS Agreement Article 73 Security Exceptions and the COVID19 Pandemic." SSRN Electronic Journal, no. 116 (2020): 1-22. https://doi.org/10.2139/ssrn.3682260.

Armstrong, David. Routledge Handbook of International Law. Edited by David Armstrong, Jutta Brunée, Michael Byers, John H. Jackson, and David Kennedy. 1st ed. New York: Routledge, 2009.

Asok, Aswathy. "Compulsory Licensing for Public Health and Usa's Special 301 Pressure: An Indian Experience.” Journal of Intellectual Property Rights 24, no. 5-6 (2019): 125-31. http://nopr.niscair.res.in/handle/123456789/54321.

Athreye, Suma, Lucia Piscitello, and Kenneth C. Shadlen. "Twenty-Five Years since TRIPS: Patent Policy and International Business.” Journal of International Business Policy 3, no. 4 (2020): 315-28. https://doi.org/10.1057/s42214-020-00079-1.

Aust, Anthony. Handbook of International Law. 2nd ed. Cambridge: Cambridge University Press, 2010.

Ayu, Putu, and Sriasih Wesna. "Doha Declaration Sebagai Perlindungan Masyarakat Atas Akses Obat Esensial Di Negara Berkembang Pasca Trips Agreement." Jurnal Warmadewa Kertha Wicaksana 14, no. 1 (2020): 56-62. https://doi.org/10.22225/kw.14.1.1585.56-62.

Barcellos, Milton Lucídio Leão. "Compulsory License in Brazil: Competition Tool or Just a Threat?" Revista de Propriedade Intelectual - Direito Constitucional e Contemporâneo 10, no. 3 (October 2016): 141-52. https://doi.org/10.16928/2316-8080.V10N3p.141-152.

Baten, Joerg, Nicola Bianchi, and Petra Moser. "Compulsory Licensing and Innovation Historical Evidence from German Patents after WWI." Journal of Development Economics 126 (2017): 231-42. https://doi.org/10.1016/j.jdeveco.2017.01.002. 
Bognar, Cinthia Leite Frizzera Borges, Brittany L. Bychkovsky, and Gilberto de Lima Lopes. "Compulsory Licenses for Cancer Drugs: Does Circumventing Patent Rights Improve Access to Oncology Medications?” Journal of Global Oncology 2, no. 5 (2016): 292-301. https://doi.org/10.1200/jgo.2016.005363.

Charnovitz, Steve. "The Legal Status of the Doha Declarations." Journal of International Economic Law 5, no. 1 (March 2002): 207-11. https://doi.org/10.1093/jiel/5.1.207.

Chattu, Vijay Kumar, Shalini Pooransingh, and Hamid Allahverdipour. "Global Health Diplomacy at the Intersection of Trade and Health in the COVID-19 Era." Health Promotion Perspectives 11, no. 1 (2021): 1-4. https://doi.org/10.34172/hpp.2021.01.

Correa, Carlos M. "Special Section 301: US Interference with the Design and Implementation of National Patent Laws.” Research Paper. Geneva, 2020.

Dörr, Oliver, and Kirsten Schmalenbach. "Article 26 Pacta Sunt Servanda." In Vienna Convention on the Law of Treaties: A Commentary, edited by Oliver Dörr and Kirsten Schmalenbach, 1-1423. Berlin, Heidelberg: Springer Berlin Heidelberg, 2012. https://doi.org/10.1007/978-3-642-19291-3.

Dowie-Whybrow, Margaret. "Paris Convention for the Protection of Industrial Property." In Core Statutes on Intellectual Property, 516-43. London: Macmillan Education UK, 2013. https://doi.org/10.1007/978-1-137-35471-6_5.

Durojaye, Ebenezer. "Compulsory Licensing and Access to Medicines in Post Doha Era: What Hope for Africa?" Netherlands International Law Review 55, no. 1 (May 2008): 33-71. https://doi.org/10.1017/S0165070X08000338.

Dziuba, Dawn. "Trips Article 31bis and H1N1 Swine Flu: Any Emergency or Urgency Exception to Patent Protection?" Indiana International \& Comparative Law Review 20, no. 2 (January 2010): 195-212. https://doi.org/10.18060/17626.

Feldman, Jamie. "Compulsory Licenses : The Dangers Behind the Current Practice." Journal of International Business and Law 8, no. 1 (2009): 137-67. https://scholarlycommons.law.hofstra.edu/jibl/vol8/iss1/9/.

Flynn, Matthew. "Brazilian Pharmaceutical Diplomacy: Social Democratic Principles versus Soft Power Interests." International Journal of Health Services 43, no. 1 (January 2013): 67-89. https://doi.org/10.2190/HS.43.1.f.

Ford, Sara M. "Compulsory Licensing Provisions Under the TRIPs Agreement: Balancing Pills and Patents." American University Journal of International Law \& Policy 15, no. 4 (2000): 941-74. https://digitalcommons.wcl.american.edu/auilr/vol15/iss4/5/.

Frazão Leme, Letícia. "Flexibilities Under Article 39.3 of the TRIPS Agreement: Protection of Pharmaceutical Test Data and the Case of Brazil." In The WTO Dispute Settlement Mechanism, edited by Alberto do Amaral Júnior, Luciana Maria de Oliveira Sá Pires, and Cristiane Lucena Carneiro, 339-55. Cham: Springer International Publishing, 2019. https://doi.org/10.1007/978-3-030-03263-0_22.

Gandhi, Bela. "India's Compulsory License Model: Increased Pharmaceutical Access and Innovation Coexist." BYU Prelaw Review 33, no. 5 (2019): 33-51. https://scholarsarchive.byu.edu/byuplr/vol33/iss1/5/. 
Gathi, James Thuo. "The Legal Status of the Doha Declaration on TRIPS and Public Health Under the Vienna Convention of the Law of Treaties." Harvard Journal of Law \& $\begin{array}{lllll}\text { Technology 15, no. 292-317. } & \end{array}$ https://lawecommons.luc.edu/cgi/viewcontent.cgi?article=1419\&context=facpubs.

Hage, Jaap. "What Is Legal Validity? Lessons from Soft Law." In Legal Validity and Soft Law, 19-45. Berlin: Cham : Springer International, 2018. https://doi.org/10.1007/978-3-31977522-7_2.

Harris, Donald. "TRIPS After Fifteen Years: Success or Failure, as Measured by Compulsory Licensing." Journal of Intellectual Property Law 18, no. 2 (2011): 1-35. https://digitalcommons.law.uga.edu/jipl/vol18/iss2/3.

Hartmann, Stephanie. "Russia - Measures Concerning Traffic in Transit (WTO)." International Legal Materials 58, no. 5 (October 2019): 899-1027. https://doi.org/10.1017/ilm.2019.40.

Haugen, Hans Morten. "Does TRIPS (Agreement on Trade-related Aspects of Intellectual Property Rights) Prevent COVID-19 Vaccines as a Global Public Good?" The Journal of World Intellectual Property 24, no. 3-4 (2021): 1-26. https://doi.org/10.1111/jwip.12187.

Haunss, Sebastian, and Kenneth Shadlen. "The Politics of Patents: Conditions of Implementation of Public Health Policy in Thailand." In Politics of Intellectual Property: Contestation Over the Ownership, Use, and Control of Knowledge and Information, 1249. Cheltenham: Edward Elgar 2009. https://doi.org/10.4337/9781849802062.

Ho, Cynthia. "Unveiling Competing Patent Perspectives." Houston Law Review 46, no. 4 (2009): 1047-1114. https://houstonlawreview.org/article/4270-unveiling-competingpatent-perspectives.

Howse, Robert, and Damien J. Neven. "United States - Section 211 Omnibus Appropriations Act of 1998 (WT/DS176): Report of the Appellate Body." In Dispute Settlement Reports 2002, edited by World Trade Organization, 589-682. Cambridge: Cambridge University Press, 2004. https://doi.org/10.1017/9781108379052.001.

Kameel, Tariq, Ramzi Madi, and Kawthar Kayed. "The Compulsory Licensing for Exploiting Patented COVID-19 Pharmaceutical Treatment: Legal Approaches of Some Arab Countries." Biotechnology Law Report 40, no. 2 (2021): 104-16. https://doi.org/10.1089/blr.2021.29225.ka.

Kaszubska, Katarzyna. “Compulsory Licensing under India's New Model Bilateral Investment Treaty." Review of Market Integration 9, no. 3 (December 2017): 139-54. https://doi.org/10.1177/0974929217744466.

Klink, Bart van, and Oliver W. Lembcke. "A Fuller Understanding of Legal Validity and Soft Law." In Legal Validity and Soft Law, 145-64. Berlin: Springer, 2018. https://doi.org/10.1007/978-3-319-77522-7_7.

Kuanpoth, Jakkrit. "Compulsory Licences: Law and Practice in Thailand." In Compulsory Licensing Practical Experiences and Ways Forward, edited by Reto M. Hilty and KungChung Liu, 61-77. Berlin: Springer Berlin Heidelberg, 2015. https://doi.org/10.1007/9783-642-54704-1_4.

Kunisawa, Viviane Yumy Mitsuuchi. “Analyzing the Brazil Case.” In The TRIPS Agreement 
Implementation in Brazil, edited by Christoph Ann, Robert Brauneis, Josef Drexl, Michael Kort, Thomas M.J. Möllers, and Joseph Straus, 1st ed., 151-78. Baden-Baden: Nomos Verlagsgesellschaft mbH, 2015.

Licks Attorneys. Brazilian Patent Statute and Selected Patent Prosecution Rules (2016). http://static.lickslegal.com/pdf/Licks Attorneys - Brazil - Selected Patent Prosecution Rules.pdf?x54306.

Lybecker, Kristina M., and Elisabeth Fowler. "Compulsory Licensing in Canada and Thailand: Comparing Regimes to Ensure Legitimate Use of the WTO Rules." Journal of Law, Medicine \& Ethics 37, no. 2 (January 2009): 222-39. https://doi.org/10.1111/j.1748720X.2009.00367.x.

Malanczuk, Peter. Akehurst's Modern Introduction to International Law. 7th ed. New York: Routledge, 2002.

Maxwell, Alice. "Plainly Justifiable? The World Trade Organization's Ruling on the Validity of Australia's 'Plain Packaging' Under Article 20 of the TRIPS Agreement." Asian Journal of WTO \& International Health Law \& Policy 14, no. 1 (2019): 115-45. https://doi.org/10.2139/ssrn.3363052.

Médecins Sans Frontières. "A Timeline of US Attacks on India's Patent Law and Generic Competition." Geneva, 2015. https://msfaccess.org/sites/default/files/2018 10/IP_Timeline_US pressure on India_Sep 2014_0.pdf.

Medicines Law \& Policy. “The TRIPS Flexibilities Database.” Medicines Law \& Policy, 2018. http://tripsflexibilities.medicineslawandpolicy.org/.

Mendez, Mario. "Constitutional Review of Treaties: Lessons for Comparative Constitutional Design and Practice." International Journal of Constitutional Law 15, no. 1 (January 2017): 84-109. https://doi.org/10.1093/icon/mox004.

Moser, Petra. "Patents and Innovation: Evidence from Economic History." Journal of Economic Perspectives 27, no. 1 (February 2013): 23-44. https://doi.org/10.1257/jep.27.1.23.

Motari, Marion, Jean Baptiste Nikiema, Ossy M.J. Kasilo, Stanislav Kniazkov, Andre Loua, Aissatou Sougou, and Prosper Tumusiime. "The Role of Intellectual Property Rights on Access to Medicines in the WHO African Region: 25 Years after the TRIPS Agreement." BMC Public Health 21, no. 1 (2021): 1-19. https://doi.org/10.1186/s12889-021-10374-y.

Murthy, Divya. "The Future of Compulsory Licensing: Deciphering the Doha Declaration on the TRIPs Agreement and Public Health." American University International Law Review 17, no. 6 (2002): https://digitalcommons.wcl.american.edu/auilr/vol17/iss6/4/.

Oke, Emmanuel Kolawole. "The Incorporation of a Right to Health Perspective into Brazil's Patent Law Reform Process." In Law and Policy in Latin America, edited by Pedro Fortes, Larissa Boratti, Andrés Palacios Lleras, and Tom Gerald Daly, 311-26. London: Palgrave Macmillan UK, 2017. https://doi.org/10.1057/978-1-137-56694-2.

Ortino, Federico. "The Obligation of Regulatory Stability in the Fair and Equitable Treatment Standard: How Far Have We Come?" Journal of International Economic Law 21, no. 4 (December 2018): 845-65. https://doi.org/10.1093/jiel/jgy039. 
Panel, WTO. Saudi Arabia - Measures Concerning the Protection of Intellectual Property Rights (2018).

Perehudoff, Katrina, Ellen Thoen, and Pascale Boulet. "Overriding Drug and Medical Technology Patents for Pandemic Recovery: A Legitimate Move for High-Income Countries, Too." BMJ Global Health 6, no. 4 (2021): 1-4. https://doi.org/10.1136/bmjgh2021-005518.

Public Eye. "Compulsory Licensing in Colombia: Leaked Documents Show Aggressive Lobbying by Novartis." Public Eye, 2017. https:/www.publiceye.ch/en/mediacorner/press-releases/detail/compulsory-licensing-in-colombia-leaked-documents-showaggressive-lobbying-by-novartis.

Ranjan, Prabhash. "Compulsory Licences and ISDS in Covid-19 Times: Relevance of the New Indian Investment Treaty Practice." Journal of Intellectual Property Law \& Practice 16, no. 7 (2021): 748-59. https://doi.org/10.1093/jiplp/jpab084.

Reichman, Jerome H. "Comment: Compulsory Licensing of Patented Pharmaceutical Inventions: Evaluating the Options." The Journal of Law, Medicine \& Ethics : A Journal of the American Society of Law, Medicine \& Ethics 37, no. 2 (January 2009): 247-63. https://doi.org/10.1111/j.1748-720X.2009.00369.x.

Reuters Staff. "India Defends Right to Issue Drug "Compulsory Licenses." Reuters, 2016. https://www.reuters.com/article/us-india-patents-usa-idUSKCNOWP0T4.

Rodrigues da Silva, Caio, and Leonor Galvão de Botton. "Compulsory Pharmaceutical Patent Licensing in Brazil: The Controversy of Public Interest." Pharmaceutical Patent Analyst 2, no. 6 (November 2013): 1-3. https://doi.org/10.4155/ppa.13.63.

Romero, Thamara. "Articles 7 and 8 as the Basis for Interpretation of the TRIPS Agreement." Geneva, 2020.

Saroha, Satish, Deepak Kaushik, and Arun Nanda. "Compulsory Licensing of Drug Products in Developing Countries." Journal of Generic Medicines: The Business Journal for the Generic Medicines Sector 12, no. 3-4 (September 2015): 89-94. https://doi.org/10.1177/1741134313503827.

Sekalala, Sharifah, and Haleema Masud. "Soft Law Possibilities in Global Health Law." Journal of Law, Medicine \& Ethics 49, no. 1 (April 2021): 152-55. https://doi.org/10.1017/jme.2021.20.

Serohina, Nataliia, Olena Pikhurets, Svitlana Iasechko, Elvira Yevlakhova, Stepan Lytvyn, and Ivan Miroshnykov. "Application of Compulsory Licensing in the Context of the Covid-19 Coronavirus Pandemic." Systematic Reviews in Pharmacy 12, no. 1 (2021): 334-42. https://doi.org/10.31838/srp.2021.1.53.

Shahnawaz, Sheikh. "The Optimal Timing of Compulsory Licensing: A Story of Thailand's Winter of Discontent." Global Economy Journal 12, no. 4 (November 2012): 1-17. https://doi.org/10.1515/1524-5861.1903.

Shaw, Malcolm N. International Law. 6th ed. Cambridge: Cambridge University Press, 2008.

Shukri, Sakinah Mohd, Johar MGM, and Jacquline Tham. "How E-Business Platform Channels Influence Chinese Auto-Parts Wholesale Market?" Systematic Reviews in Pharmacy 11, 
no. 1 (2020): 718-24. https://www.sysrevpharm.org/articles/role-of-ebusiness-in-thewholesale-market-of-china.pdf.

Sidharta, Noor, Sudarsono Sudarsono, I Nyoman Nurjaya, and Bambang Sugiri. "Judicial Preview on the Bill on International Treaty Ratification." Constitutional Review 3, no. 1 (August 2017): 24-42. https://doi.org/10.31078/consrev312.

Sihotang, Januari. "Peran Mahkamah Konstitusi Sebagai Lembaga Penguji Undang-Undang Dalam Masyarakat Ekonomi ASEAN." Dialogia Iuridica: Jurnal Hukum Bisnis Dan Investasi 7, no. 1 (2017): 37. https://doi.org/10.28932/di.v7i1.707.

Simmons, Bryony, Graham S. Cooke, and Marisa Miraldo. "Effect of Voluntary Licences for Hepatitis C Medicines on Access to Treatment: A Difference-in-Differences Analysis." The Lancet Global Health 7, no. 9 (2019): 1189-96. https://doi.org/10.1016/S2214109X(19)30266-9.

Slade, Alison. "Good Faith and the TRIPS Agreement: Putting Flesh on the Bones of the TRIPS 'Objectives."' International and Comparative Law Quarterly 63, no. 2 (April 2014): 35383. https://doi.org/10.1017/S0020589314000098.

- "The Objectives and Principles of the WTO TRIPS Agreement: A Detailed Anatomy." Osgoode Hall Law Journal 53, no. 3 (2016): 1-59. https://ssrn.com/abstract=2781664.

Solovy, Eric M., and Pavan S. Krishnamurthy. "TRIPS Agreement Flexibilities and Their Limitations: A Response to the UN Secretary-General's High-Level Panel Report on Access to Medicines." George Washington International Law Review 50, no. 1 (2017): 69-124. https://ssrn.com/abstract=2984951.

Sood, Mansi. "Natco Pharma Ltd. v. Bayer Corporation and the Compulsory Licensing Regime in India." NUJS Law Review 6, no. 1 (2013): 99-119. http://nujslawreview.org/2016/12/02/natco-pharma-ltd-v-bayer-corporation-and-thecompulsory-licensing-regime-in-india/.

Tarigan, Vita Cita Emia, and Eka NAM Sihombing. "Kebijakan Pengendalian Pencemaran Di Selat Malaka Yang Bersumber Dari Kecelakaan Kapal.” Jurnal Penelitian Hukum De Jure 19, no. 4 (December 2019): 479-502. https://doi.org/10.30641/dejure.2019.V19.479-502.

Taubman, Antony, Hannu Wager, and Jayashree Watal, eds. "Agreement on Trade-Related Aspects of Intellectual Property Rights (TRIPS Agreement) (as Amended on 23 January 2017)." In A Handbook on the WTO TRIPS Agreement, 295-337. Cambridge University Press, 2020. https://doi.org/10.1017/9781108883511.015.

Thanitcul, Sakda, and Matthew Lim Braslow. "Compulsory Licensing of Chronic Disease Pharmaceuticals in Thailand." Thai Journal of Pharmaceutical Sciences 37, no. 2 (2013): 61-83.

https://www.researchgate.net/publication/289551723_Compulsory_licensing_of_chronic _disease_pharmaceuticals_in_Thailand.

Tomoko, Yamashita. "Procedural and Normative Competition between the WTO's Dispute Settlement and the Investor-State Arbitration: Focusing on the National." Public Policy $\begin{array}{lllll}\text { Review } & 16, & \text { no. } & 5 & \text { (2020): }\end{array}$ https://www.mof.go.jp/english/pri/publication/pp_review/ppr16_05_09.pdf.

Urias, Eduardo, and Shyama V. Ramani. “Access to Medicines after TRIPS: Is Compulsory 
Licensing an Effective Mechanism to Lower Drug Prices? A Review of the Existing Evidence." Journal of International Business Policy 3, no. 4 (2020): 367-84. https://doi.org/10.1057/s42214-020-00068-4.

Usher, Ann Danaiya. "South Africa and India Push for COVID-19 Patents Ban." The Lancet 396, no. 10265 (December 2020): 1790-91. https://doi.org/10.1016/S01406736(20)32581-2.

Wong, Hilary. "The Case for Compulsory Licensing during COVID-19." Journal of Global Health 10, no. 1 (June 2020): 1-5. https://doi.org/10.7189/jogh.10.010358.

World Trade Organization. "Canada - Patent Protection of Pharmaceutical Products (WT/DS114) Report of the Panel." In Dispute Settlement Reports 2000, 2289-2582. Cambridge: Cambridge University 2002. https://doi.org/10.1017/9781108378840.002.

. "India - Patent Protection for Pharmaceutical and Agricultural Chemical Products (WT/DS79/R): Report of the Panel.” In Dispute Settlement Reports 1998, 2661-2752. Cambridge: Cambridge University 2001. https://doi.org/10.1017/9781108378697.002.

Promoting Access to Medical Technologies and Innovation, 2nd Edition. 2nd ed. Geneva: WTO, 2020. https://doi.org/10.30875/fa323700-en.

World Trade Organization Appellate Body. "United States - Import Prohibition of Certain Shrimp and Shrimp Products (WT/DS58): Report of the Appellate Body." In Dispute Settlement Reports 1998, edited by World Trade Organization, 2755-2820. Cambridge: Cambridge University Press, 2001. https://doi.org/10.1017/9781108378703.001.

WTO Appellate Body. Japan - Taxes on Alcoholic Beverages (1996).

Zolotaryova, Vera. "Are We There Yet ? Taking " TRIPS " to Brazil and Expanding Access to HIV / AIDS Medication.” Brooklyn Journal of International Law 33, no. 3 (2008): 10991126. https://brooklynworks.brooklaw.edu/bjil/vol33/iss3/10. 
